\title{
Política, economia e mediação simbólica: Notas etnográficas sobre a constituição da chefia so- cial a partir da experiência do Camelódromo de Porto Alegre?1
}

\author{
MoIsÉs Kopper
}

resumo Este trabalho problematiza as disputas e processos de instituição do Centro Popular de Compras - popular "Camelódromo" - na Região Centro de Porto Alegre/RS. Com base na realização de observação participante multi-situada, discute-se, de um lado, as estratégias de governamentalidade associadas à força persuasiva do Estado, ao colocar a necessidade de higienização e urbanização do espaço público e, com ela, o deslocamento espacial e identitário de trabalhadores informais das ruas para a visibilidade jurídico-formal. De outro lado, questiona-se os modelos de gestáo do Estado subjacentes às Parcerias Público-Privadas, à luz de sua contextualizaçáo local, isto é, dos camelôs afetados pelo processo de transição. $\mathrm{O}$ acompanhamento etnográfico dos itinerários de seu líder comunitário - Juliano Fripp -, conectando diferentes espaços da esfera pública (Câmara Municipal, Ministério Público, Prefeitura, Orçamento Participativo) às expectativas do grupo, permite entrever como se configuram as tensóes mais amplas em torno dos processos político-econômicos que atravessam a instituição do Camelódromo.

palavras-chave Camelódromo. Transição. Comércio informal. Mediação política. Estado.

Na iminência de completar o primeiro ano de atividades, ainda é cedo para sugerir a ideia de que o Camelódromo de Porto Alegre está instituído e funciona com suas próprias engrenagens e roupagens. Localizado na Praça Ruy Barbosa, em pleno "coração" da cidade - a algumas quadras da Prefeitura Municipal, do Mercado Público, e em duas das vias de comércio popular mais frequentadas por compradores de todo o estado -, o "Camelódromo", ou "Shopping do Porto", na versão de seus idealizadores, ainda é uma surpresa para grande parte dos transeuntes, habituados ao cenário das compras de oportunidade, em vários pontos estratégicos das ruas do centro da cidade.

Do ponto de vista simbólico, o processo de transição suscitado pelo deslocamento de comerciantes populares das ruas para um empreendimento público permite considerar a instituição do Camelódromo enquanto sistema - na acepçáo sociológica do termo - na medida em que conecta, de maneira indissociavelmente política e física, a atuação pública de pelo menos três modalidades de agentes diferenciados que, entre outras coisas, do ponto de vista ideal, teriam o objetivo de discutir os critérios de operação e consolidação desta que é a primeira parceria público-privada da cidade ${ }^{2}$. Há, de um lado, os agentes estatais (prefeitura municipal, secretarias de gestão, indústria e comércio, câmara de vereadores); de outro lado, os grupos sociais pleiteantes e afetados pelo processo são estes os camelôs e comerciantes informais que durante várias décadas ocuparam as ruas do centro da cidade e que repentinamente se veem na iminência dos processos de legalização e de negociação com o Estado, transfigurando uma relação historicamente pontuada pela oposição e pelo distanciamento sistemático da 
esfera pública. Há, ainda, um terceiro grupo de agentes - são os representantes da construtora do empreendimento - a empresa "Verdicon Construções" -, com quem os camelôs deverão manter, doravante, uma relação contratual, jurídica e comercial de locação dos novos espaços de trabalho.

O projeto de concepção e planejamento de um Centro Popular de Compras que abrigasse os camelôs e comerciantes informais do centro de Porto Alegre não é um processo recente e precisa ser entendido a partir do campo de possibilidades macrossociológico que o instituiu. Se a sua implementação só se tornou possível nos últimos anos, é porque as alteraçóes no modo de gestar e gerir a máquina estatal (Souza Lima, 2002) trouxeram novas questóes, novas políticas públicas e, por extensão, novas "necessidades" e injunções para fazer cumprir e levar a cabo o processo de reurbanização e higienização da Região Centro de Porto Alegre ${ }^{3}$ que, por sua vez, é parte de um conjunto de políticas de gentrificação do espaço público urbano (Leite, 2001; 2002). Trata-se de compreender o processo de transição a partir de suas interfaces com as estratégias de governamentalidade (Foucault, 1979) associadas à força persuasiva do Estado: é no interior desse contexto mais amplo - que tem por escopo, entre outras coisas, a tentativa de produção de uma memória e de uma espacialidade legítimas, baseadas no ideal da cidade cosmopolita e pretensamente multicultural, que a questáo do camelódromo foi politicamente enunciada, discutida e implementada. O Estado opera, aqui, como um agente privilegiado nesse sistema de posiçóes relativas, cuja constituição histórica não é menos relevante para o entendimento dos entrecruzamentos e tensionamentos entre as políticas públicas relativas às imagens associadas ao centro histórico e à ocupação do espaço urbano, de um lado, e os usos efetivos, individuais e coletivos, desenha- dos pelos cidadãos na arquitetura social e simbólica da cidade, de outro.

O ponto fundamental está em que a instituição de um espaço de produção de pequenos comerciantes populares - em substituição à categoria de "camelô" - está amparada por um projeto moderno de legalização e visibilização da mão de obra trabalhadora, de vez que passa a concentrar vendedores "ambulantes" - isto é, dispersos pelas ruas, sem ponto fixo e, portanto, sem grandes chances de fiscalização legal contínua - em um único e denso espaço, em uma região geopolítica estratégica para a vigilância e o esquadrinhamento de suas movimentaçôes e ações. Do ponto de vista subjetivo, porém, esse movimento objetivo traz um desajuste cognitivo que coloca em suspenso antigas categorias de avaliação e apreensão da realidade, ao mesmo tempo em que busca inscrever, nesse habitus em transfiguração (Bourdieu, 1983; 2001), novas estruturas ou parâmetros de inteligibilidade, associadas a mudanças em termos de projetos de vida (Velho, 1981). Por sua vez, isso se reflete em modificaçóes linguísticas e perceptivas, isto é, no modo como reconhecem a si mesmos como sujeitos dessas novas experiências, um modo de narrar e de estar na história e na modernidade.

Se, como quer Sahlins (1997), a conjuntura atual impõe a investigação dos múltiplos processos de indigenização do mundo moderno, então uma das chaves interpretativas para a compreensão da dinâmica das configuraçóes que tem por pano de fundo a implantação de um modelo específico de camelódromo está em partir, do ponto de vista metodológico, das estratégias de "resistência cultural" empreendidas por diferentes grupos de camelôs na adequação e apropriação desse projeto. A dinâmica da transição, entendida enquanto um espaço-tempo sui generis a meio caminho entre a cosmologia da rua e o código idealizado subjacente ao Camelódromo, fica mais bem 
definida a partir dos itinerários daqueles indivíduos que, a partir da constituição de um trajeto de resistência, ou de um projeto coletivo de deslocamento, impóem restriçóes, tensóes e ressignificações em relação à intervenção estatal - fundamentada, por sua vez, na ideia de uma conversão total à perspectiva individualizadora (pois que produtora de um novo self) e esquadrinhadora subjacente ao projeto de urbanização da cidade. Torna-se possível indagar, assim, de uma perspectiva micro-processual, a respeito dos contextos de produção e elaboração da paisagem imagética e mitoprática da transição, a partir dos trajetos espaciais e temporais específicos (De Certeau, 1994) pelos quais os comerciantes populares se apropriam semanticamente dos novos espaços de ambiência da sociabilidade (que são também espaços de comércio, mas de fluxos de imagens e objetos constitutivos de um comércio dependente e construído a partir desses itinerários e movimentos pelas ruas, calçadas, bancas e corredores do Camelódromo).

\section{A ASFERAP e os caminhos delineados pelo processo de transiçáo}

No seio da clivagem entre os blocos A e B do empreendimento ${ }^{4}$ - que significa, também, uma sedimentação entre as várias perspectivas de atuação política e social dos comerciantes -, venho acompanhando etnograficamente as manobras e os itinerários de um grupo de camelôs que estiveram à testa da discussão dos processos de implementação do Camelódromo em Porto Alegre. Trata-se da Associação Feira Rua da Praia (ASFERAP), fundada em 2001 pelo seu atual presidente - Juliano Fripp -, com o objetivo inicial de escapar ao rótulo estereotipado da categoria de "camelô", valendo-se, em detrimento, da expressão - politicamente mais polida e amena - de "feirante" para justificar a sua atuação ao longo da Rua dos Andradas, localizada no centro da capital gaúcha. Seus pouco mais de duzentos membros, de início constrangidos pela carregada expressão "camelô" - já que, como micro-produtores independentes de artigos de vestuário, consideravam-se algo "mais" que vendedores de quinquilharias - passariam, com a implantação e as consequências do projeto do Camelódromo, a reinventá-la e mesmo invocá-la em favor de uma categorização identitária do movimento social, como o baluarte das lutas e disputas políticas que seriam travadas para resguardar seu direito de permanência nos boxes do shopping popular.

A trajetória da transição e os significados desse percurso de resistência, tornada inteligível pelos usos estratégicos e públicos da palavra narrada e pela circulação por diferentes espaços públicos de Porto Alegre, pode, assim, ser mais bem descrita a partir dos itinerários de Juliano Fripp e de sua comunidade 5 . Nesse sentido, as próximas páginas são uma tentativa de esboçar, em linhas gerais, as principais características e pontos de referência por onde se delinearam as disputas e negociaçóes do primeiro ciclo do processo de transição para o Camelódromo, cuja demarcação inicial pode ser situada, do ponto de vista metodológico ${ }^{6}$, no ritual de inauguração do prédio, bem como o seu desfecho, na expropriação, por meio de despejo e litígios jurídicos, da primeira leva de comerciantes populares (entre os quais se inclui, também, a banca de Juliano).

Filho de pequenos agricultores, atualmente residente em Esteio, região metropolitana de Porto Alegre, Juliano, como liderança comunitária, intersecta em suas movimentações e estratégias discursivas uma diversidade de agentes e instituiçóes sociais. Trata-se, pois, de privilegiar um ponto de vista particular, ainda assim coletivo - uma dada posição social no campo de forças e de possibilidades culturais 
-, que é atravessado pelos processos globais e macro-sociais em gestação num recorte temporal e espacial específico.

Começar a falar em Camelódromo, pra mim, pra muitos é bem antes, mas pra mim é falar em 1990, quando a gente foi pra Rua da Praia trabalhar com o comércio informal, por uma questão de necessidade pura, por não ter emprego [...]. E lá a gente encontrou muita gente como a gente, que por necessidade extrema acabam indo pra rua, porque é a única forma que as classes dominantes deram pra nós e continuam dando. Então na rua a gente achou a dignidade, a maneira de poder trabalhar e sobreviver. Então esta luta começa desde 1990, a gente se organizando pra chegar o momento de que os espaços que a gente pudesse trabalhar fossem dignos, um espaço que a gente pudesse mostrar pra sociedade o valor que nós temos ${ }^{7}$.

O debate dirigido em torno da concepção de um projeto de Camelódromo que acomodasse grande parte do trabalho informal distribuído quase que aleatoriamente pelas principais calçadas e avenidas do centro da cidade ganhou forma a partir de 2002, com a elaboração de um shopping vertical fundamentado no projeto arquitetônico de Belo Horizonte, que viria a ser apresentado em 2005 aos então "ambulantes” pela Secretaria Municipal de Produção, Indústria e Comércio (SMIC).

Aí a gente já via a ânsia dos políticos, a ânsia da sociedade, de tirar nós da rua. E começamos desde aquela época a se organizar pra ter esse espaço digno. [...] Fizemos uma grande manifestaçáo em Porto Alegre rechaçando a ideia do Camelódromo vertical. Fizemos uma grande passeata, lotamos o plenário, entregamos um abaixo-assinado com $15 \mathrm{mil}$ assinaturas, dizendo que espaço de camelô era na rua! Era espaço horizontal! E partir daquele momento surgiu a ideia do camelódromo horizontal na Ruy Barbosa. [...] E nós, AFERAP, com muito orgulho, aceitamos, porque ali a gente via um espaço horizontal digno dum grande movimento, que atraía muitas pessoas pro seu terminal pra continuar sendo nossos clientes. A partir desse momento a gente começou a trabalhar com o secretário Leo Bulling a construção do projeto desse camelódromo ${ }^{8}$.

Com efeito, as incursóes entrecruzadas de diferentes segmentos representantes do comércio informal - entre os quais, destacadamente a ASFERAP, através da agência discursiva de seu presidente fundador - produziram uma série de disputas e negociações que envolvem o acionamento reiterado de múltiplas esferas do Estado e da Justiça, cuja análise exaustiva escapa aos objetivos circunscritos por este artigo? O ponto a destacar, contudo, está que tais contextos de discussão permitiram ao líder comunitário a experiência subjetiva da participação na tomada pública das decisóes a respeito da condução da política paisagística, arquitetônica, social e econômica da cidade, de tal forma que lhe autoriza colocar a questão como resultado de um acordo de diferentes partes, em que a sanção e a deferência da ASFERAP desempenharam, supostamente, papel central. É a partir desta experiência, portanto, que a aceitação do projeto horizontal de camelódromo adquire sentido. Não obstante, trata-se, aqui, apenas, de um acolhimento parcial, posto que dependente de quais sejam as condições simbólicas relativas à preparação do processo de transição, e a quem caberá enunciá-las. Se a aliança com os agentes estatais se faz possível, ela só pôde se tornar pensável na medida em que representou a possibilidade remota de barganha dos termos e critérios objetivos do deslocamento ${ }^{10}$.

Aí começa uma luta que a gente desde o início acreditou que seria verdadeira. [...] Assim como 
os vereadores acreditaram nesse camelódromo, nós também acreditamos nele. Acreditamos que as propostas que a gente tava levando pro então secretário seriam aceitas. Acreditamos que os espaços seriam de 2 por 2 . Acreditamos que o valor seria de $\mathrm{R} \$ 200$ a $\mathrm{R} \$ 250$. Acreditamos que a gente teria acesso à engenharia da obra, porque é a nossa segurança, de quem vai estar lá dentro daquele espaço, que ta em jogo. Só que nada disso aconteceu! [...] Nós entramos na justiça, e infelizmente perdemos na primeira instância! E fomos lá escolher os pontos porque a SMIC ia usar isso contra nós. Nós chamamos a ASFERAP e fomos lá escolher os nossos pontos, os últimos a escolher, os últimos! Porque a gente tentou até o fim! Escolhemos o nosso ponto pra não perder. Mas mesmo assim a gente não se entregou e não vai se entregar ${ }^{11}$.

Com a primeira data concreta de inauguração do prédio prevista ainda para dezembro de 2008 - o que já correspondia a um significativo alargamento dos prazos estipulados pelo projeto, inicialmente planejado para o mês de setembro do mesmo ano - a discussão em torno dos critérios de acesso aos espaços (tais como as dimensões dos boxes, os valores semanais de aluguel e condomínio, a distribuição das 800 vagas pelos diferentes segmentos do comércio informal) cedeu lugar às tentativas de postergação do processo de deslocamento e, por extensão, de inauguração da obra. Ainda em meados de outubro, uma reunião entre cerca de dez grupos organizados de camelôs, a SMIC e a Secretaria Municipal de Gestão e Acompanhamento Estratégico definiu que a apropriação dos espaços seria transferida para janeiro de 2009 - a fim de que os comerciantes pudessem aproveitar as vendas de fim de ano, ainda nas ruas, e inaugurar, com a chegada do novo ano, uma "nova etapa" em suas condiçóes e projetos de vida e, particularmente, nas expectativas e processos de comercialização.
Por outro lado, o mês de dezembro, apesar do fluxo de vendas que caracteriza essa época do calendário comercial, não elidiu a formação paulatina do estado de liminaridade social, desencadeado pela iminência da ruptura para com a rua (afinal a inauguração do prédio era concomitante à promulgação da lei que proibia o comércio nas vias do centro da cidade), e o estabelecimento de um novo horizonte de percepção ou imaginação (Crapanzano, 2005). Os jornais da época não cessavam de revelar as manifestações de insatisfação e insegurança que tomavam conta dos camelôs afetados, perfilados no entorno da Praça XV, da José Montauri, da Vigário José Inácio, da Feira da Rua da Praia, da Praça Osvaldo Cruz, da Campos Sales, ou da Feira da Praça da Alfândega. Aos poucos, surgiram as primeiras contestações abertas ao projeto de formação de microempresários, na medida em que implicavam, por extensão, a extinção da categoria "camelô"; as primeiras formulaçóes em torno da reivindicação de um prazo de carência do valor dos alugueis, bem como da revisão e do zoneamento dos seus valores, adquiriram voz no discurso dos líderes de algumas associaçóes de camelôs, entre as quais a ASFERAP.

A maturação imagética da materialização, lenta e gradativa, de uma experiência de transição, permitiu entrever e projetar, como que por uma espécie de antevisão, o malfadado "destino" que estaria reservado aos novos lojistas a partir dos encargos decorrentes do processo de legalização demandado pelo poder público. Inúmeras e exaustivas comparações desse tempo concomitantemente futuro (que encerrava um devir, um inesperado reservado) e passado (que podia ser antevisto, suas consequências permitindo ser de alguma forma prefiguradas) com a experiência vivida da rua estavam por instituir as fronteiras de um novo espaço-tempo a partir do qual os acontecimentos pregressos seriam recolocados em novos quadros 
de narração, sua semântica esvaindo-se e consubstanciando novos argumentos para a elaboração da transição. Uma nova imagem da rua estava em processo de lapidação, uma rua que pudesse fazer frente ao "destino" simbólico que inelutavelmente os aguardava e a partir de cuja perspectiva as piores agruras do tempo vivido (as intempéries da natureza, as incertezas das vendas de oportunidade, etc.) eram mais desejáveis que o mais tênue sinal desse novo horizonte que estava por ser desenhado, ou melhor, que redesenharia a própria imagem perceptiva e subjetiva desse horizonte, desse sujeito que imagina e projeta.

O debate travado naquele momento inseria-se, portanto, num quadro mais amplo acerca das diversas postergaçóes com relação à inauguração do prédio sugeridas pela intervenção de movimentos sociais e de líderes comunitários - particularmente, através do acionamento da esfera pública, do Ministério Público e dos meios de comunicação - e homologadas (traduzidas), pelo governo municipal, nos termos jurídicos apropriados à caracterização do atraso nas obras (tais como a interdição do prédio em função de problemas infraestruturais, da estipulação de critérios relativos à segurança, ou ainda de irregularidades decorrentes do processo de licitação e de fiscalização da obra). De outra parte, as estratégias de postergação significavam uma alternativa de resistência ao futuro incerto e imprevisível projetado pelo sentido do jogo incorporado dos camelôs afetados, materializada, por sua vez, na criação de figuras e narraçóes mitopráticas de periculosidades que operam como signos e depositórios materiais de expropriação ou extravasamento dos sentimentos e emoçóes associadas e acionadas pelo processo de transposição física e cultural da rua para a "gaiola", como fazem questão de ressalvar.

Uma assembleia realizada pela ASFERAP no dia 9 de janeiro, que concentrou cerca de 150 pessoas oriundas de diferentes segmentos e redes de sociabilidades distribuídas pelos espaços das ruas do centro, além de autoridades municipais e consultores de marketing empresarial - teve o seu desfecho coroado com a apresentação de um documento, homologado pela Promotoria de Justiça de Habitação e Defesa da Ordem Urbanística - órgão subjacente ao Ministério Público -, que apresentava uma listagem das exigências técnicas a serem sanadas para a ocupação do prédio. Após uma série de negociações e intervençôes estatais, de vigas que subitamente apresentavam rachaduras, de incompletudes na estrutura de segurança, de lapsos na sinalização do prédio, de modificações de última hora nos dispositivos de prevenção a incêndios - enfim, desse conjunto de elementos pré-figurados que permitiram a elaboração nativa de uma série de narrativas metonímicas e metafóricas, de lendas urbanas catastróficas sobre a destruição prematura do prédio com a consequente morte dos comerciantes populares $^{12}-$, o complexo foi aberto à população no dia 9 de fevereiro de 2009, segunda-feira, e a proibição do comércio informal nas vias públicas, declarada e notificada oficialmente às nove horas da manhã do mesmo dia.

$\mathrm{O}$ evento contou apenas com a presença do então secretário da SMIC, Idenir Cecchim - que declarou o novo espaço definitivamente inaugurado e consagrado pela população após o primeiro ato de compra no local, que ele mesmo veio a realizar. O gesto simbólico foi amplamente noticiado pela mídia, propagandeado enquanto o início de uma nova era do comércio popular - não mais informal -, bem como o "pontapé inicial" para o grande "canteiro de obras" que teria por objetivo final a reformulação e restauração histórica da região central de Porto Alegre ${ }^{13}$. Como os meios de comunicação também fizeram questão de (re) afirmar, o ritual de passagem implícito na abertura do novo prédio trazia consigo, também, a suspensão e sanção de multas relativas ao co- 
mércio informal nas ruas do centro (de cerca de $\mathrm{R} \$ 1.200,00$, de acordo com o secretário municipal, aplicáveis a qualquer ambulante irregular, seja nas ruas, seja no Camelódromo), isto é, de um corpo jurídico que deverá, doravante, ser observado e aplicado por intermédio dos fiscais estatais, encarregados de fazer cumprir os desígnios da lei, auxiliados pela Brigada Militar na tarefa de execução, e pelos administradores da empresa que detém a concessão do espaço, para a fiscalização dos novos comerciantes, do cumprimento da nova rotina (traduzida na pontualidade, assiduidade, na comercialização de produtos legalizados e autorizados pelo Estado, etc.).

Com a inauguração, Juliano tratou de fundamentar e institucionalizar sua posição (e reputação) como o líder comunitário mais adequado e apto ao exercício da função de mediador político, cargo que o acúmulo de capitais e habilidades, como a arte retórica, o uso público da palavra e a rede de sociabilidades e competências técnicas e pessoais lhe conferiam. Nesse sentido, lançou imediatamente tão logo abriram-se os espaços de trabalho - a sua candidatura ao Comitê Gestor do Camelódromo, órgão instituído pelo estatuto interno e composto por uma representação tripartite que inclui um membro da SMIC, outro da empresa que obteve a concessão (Verdicon Construçôes) e três comerciantes populares titulares de bancas. De fato, o processo de escrutínio pelo qual Juliano foi eleito e consagrado representante oficial dos comerciantes populares, obtendo mais da metade dos votos válidos, teve lugar no dia 16 de fevereiro de 2009, portanto, na semana seguinte à abertura do complexo.

$\mathrm{O}$ rito de passagem, além de permitir demarcar dramatizada e cerimonialmente a transição de status de Juliano no que tange ao seu processo de representação e de acesso aos espaços de uso público da palavra, é fundamental para a compreensão dos caminhos delineados por aqueles camelôs que percebiam na possibilidade de representação de seus interesses - e, consequentemente, na necessidade de formação de uma comunidade de pertencimento o único caminho possível para a produção de um espaço subjetivo capaz de acomodar um determinado projeto coletivo de produção da transição. Aqui, é o líder que dará o tom da narrativa e, subsequentemente, o espaço dos possíveis simbólicos para a edificação dos símbolos de percepção da transição por parte do comerciante ordinário que dramatiza esse pertencimento ao grupo: sem essa elaboração, sem essa "condução", as estratégias de resistência não poderiam ser canalizadas pelos interstícios do poder enquadrador do Estado.

Juliano procura, pelas estratégias que coloca em prática, amalgamar e conectar os dois mundos em tensão, ao aventar, por exemplo, a minoração das rupturas (a própria ideia de horizontalização dos novos espaços sugere a minimização dos esforços necessários à transposição da escada de acesso do prédio $^{14}$ ), ou ao manter intacto o nome de sua associação após o deslocamento para o Camelódromo (propóe-se, aqui, que o nome simboliza e tipifica o pertencimento identitário que o líder dramatiza enquanto mediador, e a sua alteração poderia descrever a própria tentativa de conversão ao projeto individualista). Juliano busca, ainda, enquanto representante institucionalmente empoderado, o caminho da negociação das condiçôes de comercialização, na tentativa de fazê-las convergir às expectativas de sua comunidade através da proposição de períodos de carência ou zoneamento do valor dos alugueis - trata-se, enfim, de emular, em todos os aspectos materiais e existenciais, as dimensôes da experiência vivida nos contextos da rua. Uma vez captados e produzidos, portanto, os pontos de amarração que engendram a ponte simbólica, caberá ao líder organizá-las em termos de um mapa ou programa de itinerários a partir de cujo devir o 
40 | MoISÉs Kopper

fenômeno de transição deverá ser vivenciado.

Esse "trajeto" de resistência (De Certeau, 1994), o líder o construirá recorrendo às mesmas instituiçóes que outrora colocaram, discutiram e aprovaram, em termos legais e jurídicos, seja a necessidade de transposição, seja a tramitação imprescindível à construção da obra. É assim que, após os dois primeiros meses de atividades - marcados por turbulências, confusôes e tímidas tentativas de negociação interna das condições de comercialização e de divulgação do novo empreendimento que, de outra parte, recrudescem as diferentes perspectivas de engajamento subjacentes à apropriaçáo do novo espaço - Juliano convoca a todos os "comerciantes" com espírito e identidade de "camelôs" a assumirem seu quinhão de responsabilidade e comparecerem à Tribuna Popular da Câmara de Vereadores, que veio a ser realizada no dia 30 de abril de 2009. O evento reuniu cerca de 600 camelôs no auditório principal da casa: iniciava-se, naquele momento, o processo de mediação política encabeçado por Juliano e sua comunidade, na tentativa de estabelecer pontes de comunicação com os espaços da Câmara, que repercutiriam, em longo prazo, na realização de seis reunióes do Comitê Gestor do Camelódromo com a Comissão de Finanças e Tributação (CEFOR), distribuídas entre os meses de maio e outubro de 2009.

\section{A politizaçáo da transiçáo: comunidade como ator político}

Do ponto de vista dos fundamentos da eficácia simbólica decorrentes das tentativas estratégicas de politização das experiências de transição na esfera pública (particularmente, como é o caso, na Câmara de Vereadores), é preciso reconhecer que a mediação política do líder comunitário - autorizado a fazer uso da palavra e constituir uma narrativa parti- cular do processo - passa a ser articulada em duas direções: é dirigida aos vereadores, para sensibilizá-los, e à comunidade que compóem a plenária. Ao mesmo tempo em que está com um pé na Câmara de Vereadores, compreendendo sua dinâmica operacional e o sentido do jogo que ali se desenvolve, também cumpre articular as expectativas daqueles que esperam por uma decisão, mas cuja lógica discursiva de racionalização do tempo vivido se referencia ao léxico das experiências próximas de vida e que não contemplam - nem se espera que o façam - a lógica do campo burocrático e estatal (Bourdieu, 1996). Enquanto um agente limítrofe - seja na interação com o sistema de agentes e os espaços de posiçóes que eles ocupam na política convencional, seja como ator social deslocado em relação à comunidade - o líder é simultaneamente prisioneiro do seu desejo de prestígio e da sua impotência para realizá-lo, dado que a fonte de seu poder político reside alhures, na própria sociedade que o institui e constitui (Clastres, 1979).

O papel desempenhado pela comunidade presente é de caráter complementar, mas nem por isso menos relevante, à eficácia da performance: o escutar atento e o vasto repertório de intromissões ritualizadas à fala do líder, em momentos estratégicos ao jogo social que se desenvolve, contribuem para corroborar as palavras proferidas por Juliano junto ao "parlatório". Elas obedecem a toda uma lógica culturalmente orquestrada sobre como devem ser utilizados os aplausos e as ovaçóes interpostas com fins à propulsão do discurso encenado (Ghasarian, 2007). Ainda mais importante: elas demonstram publicamente a anuência e o apoio que o orador possui da comunidade em nome da qual está autorizado a falar, a partir de uma certa margem admissível de manobras experimentais e criativas, do ponto de vista das estratégias discursivas e da manipulação dos valores e expectativas êmicas da comunidade. Sem a sua presença - equi- 
vale a afirmar, sem a presença e a ostentação de toda a rede de reciprocidades (que implicam posiçóes relativas num dado sistema social de que se é parte, no caso, o Camelódromo) a mostrar a posição de onde se está falando -, as palavras e toda a arte oratória de Juliano não teriam a mesma eficácia.

Portanto, a dinâmica do acionamento da Câmara de Vereadores - desde a Tribuna Popular até as reunióes realizadas no âmbito da Comissão de Finanças e Tributação - a partir de uma dada comunidade de comerciantes populares - entendida como ator político de reivindicação de direitos culturais e sociais -, coloca uma diversidade de perspectivas possíveis para a compreensão que essas interfaces entre economia, sociedade e política sugerem. A dinâmica e a simbologia do discurso narrado - enquanto linguagem performática do corpo, das emoçóes e das palavras - nesses espaços e tempos demanda uma certa acomodação simbólica e sensível como prestação prévia à exigência do contra-dom, que é entendido pelos comerciantes como o comprometimento do interlocutor - o poder público, através dos vereadores - com as expectativas e o ponto de vista do grupo demandante.

Do ponto de vista da subjetividade do sujeito orador, o uso retórico de uma economia corporal é um dos elementos estéticos mais significativos para o entendimento da eficácia simbólica do discurso público de Juliano. Os dedos em riste, as vociferaçóes, os xingamentos, as feições de insatisfação e indignação que acompanham as palavras proferidas, tentando contornar a baixa estatura; enfim, as movimentações físicas, as tergiversações, são componentes idiossincráticos de sua hexis corporal, que atestam um estilo subjetivo de expressão que caracteriza o líder comunitário. Todo o corpo é envolvido na argumentação: a voz que não hesita, incansável e sempre mantida em alerta, com seu som áspero e agudo, afinada com o tom de denúncia inerente às palavras; a feição do rosto, que paulatinamente vai se intumescendo, à medida que progride na argumentação e elenca os fatos tidos como insatisfatórios e irregulares, etc.

O segundo semestre de 2009 iniciou em meio a um clima de tensão e efervescência para os comerciantes populares envolvidos com a mobilização política na Câmara de Vereadores. De um lado, o evento da Tribuna Popular, em meados de abril, produziu um ambiente de expectativas positivas com relação ao tão propalado e aguardado papel de intermediação das autoridades públicas em relação aos conflitos que se acumulavam entre os comerciantes inadimplentes e a administração do Camelódromo. De outro, a intensidade dos debates durante as primeiras reunióes na CEFOR, realizadas num intervalo de apenas duas semanas - com a presença maciça de vereadores e, inclusive, do próprio secretário Idenir Cecchim - deu novas razóes que motivaram esses comerciantes a acreditar numa possível solução dessas pendengas, ao mesmo tempo em que fortaleciam e recrudesciam os ânimos para suportar as incertezas da transição, materializadas e acumuladas nas dívidas, nos problemas e nas crises de identidade. $\mathrm{O}$ mês de junho, contudo, arrefeceu as tramitações - foi realizada apenas uma rápida e protocolar reuniáo que sequer contou com a presença de todos os vereadores envolvidos com a comissão.

Era preciso dar nova prova dos interesses e expectativas que conduziam esses sujeitos ao espaço público: a reuniáo do dia $1^{\circ}$ de julho lotou um dos auditórios da casa, trouxe interessados de diversos segmentos da Câmara - mesmo aqueles que, aparentemente, procuravam certo distanciamento político em relação à questão do Camelódromo. Juliano iniciou sua performance com a "denúncia" de que "foi plantada" a "informaçáo" de que a CEFOR estaria desinteressada pela causa coletiva dos camelôs, 
e que não haveria mais interesse de dar prosseguimento aos procedimentos de negociação: “isso é normal acontecer lá dentro, onde as pessoas praticam terrorismo, assustando as pessoas que são as verdadeiras donas do Camelódromo”. Insistiu em que grande parte dos acordos estabelecidos nas reunióes anteriores (como a suspensão das notificaçôes por inadimplência até que estivessem concluídas as negociaçóes) não havia sido respeitada pelo administrador da empresa, Noedi Casagrande - que retrucou, em seu favor, salientando que o projeto do $\mathrm{Ca}$ melódromo instituía, ao contrário do que se pressupunha, uma relação de caráter privado (e não social) entre locador e locatário, o que o autorizava a exigir os prazos de pagamento e de despejo, amparados pela lei, se necessário. Este foi, seguramente, um dos discursos mais efusivos e emocionalmente carregados de Juliano, ao longo das reunióes na Câmara: era preciso, de alguma forma, tornar a canalizar e captar a atenção de seus interlocutores para o problema que assolava sua comunidade; o emprego dessas táticas narrativas procurava dar conta, portanto, do lapso de sentido e de distância social que era preciso transpor através do discurso. Um pequeno trecho de sua performance dará o tom acalorado inaugurado por Juliano para a condução dos debates.

Eles tão coagindo, fazendo terrorismo, e tentando trocar as pessoas dentro dum espaço que não pode ser trocado nesse momento. [...] E essas pessoas todas acreditaram no projeto, e ele não ta dando certo. E aí, vamos matar todo mundo, Casagrande?? Vamos atirar todo mundo na cadeia?? Vamos botar todo mundo na Justiça, e ficar devendo o resto da vida pra ti, pra empresa e pra secretaria?? Nâo!!! Não mesmo!!! [aplausos efusivos vindos da plenária] Não pode!! [aplausos e gritos continuam] Vocês têm obrigação com nós, vocês têm obrigação com esse povo! [...] A gente tentou pedir pro Casagrande a lista do cadastro das pessoas que tavam devendo, pra gente fazer uma proposta. Foi negado pra nós! Foi negado com o argumento de que é expor as pessoas... Mas que expor as pessoas?! Nós fomos eleitos por essas pessoas pra representar eles... Estranhamente eles não deram o cadastro, mas largaram essas notificaçóes. Isso é expor! Isso é humilhar as pessoas!

- Eéééééhhhhhhh!!!

- E os amigos do rei tão muito bem [aplausos e gritos efusivos]!! Tão vendendo muito bem, eles não querem movimento... Eles querem permanecer dentro do camelódromo e conquistar cada vez mais espaços... Três, quatro, cinco, seis lojas!! E tirando de pessoas que tão mal [aplausos e manifestaçóes]!! Enquanto nós fizemos um movimento, eles chegam que nem urubu na carniça e se aproveitam, enganam as pessoas dizendo que tão fazendo bem pra todo mundo. Mas isso aqui [aponta para a plenária] é a prova de que vocês não fizeram bem pra ninguém! Vocês só fizeram mal! Só fizeram mal [aplausos efusivos]!! Vocês tão destruindo uma categoria de trabalhadores que acreditam naquele Camelódromo! (...) Vocês botaram nós em jaulas lá dentro! E tão fazendo nós sofrer [gritos e aplausos]!! As pessoas tão enlouquecendo lá dentro!!!!

Ao longo do restante do mês de julho e de boa parte de agosto a questão não tornou a ser discutida na Câmara. Enquanto as pessoas pareciam cada vez mais assombradas pela postergação das decisóes e negociaçóes, o acúmulo das dívidas de aluguel sem uma resolução objetiva, Juliano continuava atipicamente sereno. Várias são as pessoas que, no cotidiano da experiência da transição, nos boxes e corredores do Camelódromo, interceptam o trajeto de seu líder para perguntar-lhe sobre o andamento das reunióes, ao que ele retruca, simples e vagamente, "que as coisas estão avançando". Esses momentos de convocação para dar explicaçóes são, portanto, as ocasióes em que compete pro- 
ceder à adequação e compatibilização da morosidade da burocracia estatal com a premência das demandas locais; dos interesses dos políticos de ofício com os interesses comunitários:

Eu não me preocupo muito com isso, porque enquanto a coisa ficar assim, em suspenso, eles não vão poder fazer nada. A SMIC não vai poder despejar porque eles vão estar desrespeitando a Comissão instituída e a Câmara Municipal. [...] Mas nós não podemos pagar o aluguel, porque nós não estamos vendendo o suficiente para isso. Ninguém pode pagar! Se eu começo a pagar o aluguel, e daqui a pouco o nosso amigo ali não vai ter condiçôes de pagar aí a gente vai estar ferrando com ele! Nós temos que segurar junto! Nós temos que lutar pela nossa anistia!! Porque a ideia do Cecchim é fazer uma lavagem cerebral na gente, ele quer convencer a gente que o problema é nosso, tá nas nossas bancas, nas nossas mercadorias. Nós temos que segurar junto e vamos até a frente da prefeitura para protestar! Nós não podemos deixar que eles nos desarticulem aqui dentro, nós temos que conservar a unidade do movimento a todo custo!

A Juliano caberá, portanto, reconhecer e avaliar a ambiência simbólica e o tom subjetivo dos estados emocionais daqueles indivíduos que estão sob o seu jugo enquanto líder comunitário, e canalizar tais experiências de modo a produzir efeitos de mediação política, isto é, a operarem como conectores eficazes no âmbito das reunióes na Câmara de Vereadores ou dos protestos em frente à prefeitura.

Do jeito que estão as coisas, as pessoas tão querendo desistir, fazer protesto, voltar pra rua. Desse jeito não dá, tem que fazer tudo dentro dos direitos, da mobilização pacífica. [...] Mas de qualquer modo na próxima reunião da Comissão de Finanças a gente vai cobrar uma posição mais incisiva dos vereadores, porque eles continuam nessa de que nada está acontecendo. Eles têm que deixar de usar isso como palanque eleitoral! Nós vamos dar um ultimato! Dependendo da resolução, a gente vai dali direto pra frente da prefeitura. E na terça aquela Câmara vai ser pequena pro nosso movimento. Até o bloco A vai ir, eles também não tão mais vendendo tão bem assim.

Com efeito, o tom da fala de Juliano aponta para a formulação gradativa de uma inversão nas estratégias de condução da agência do grupo de comerciantes na esfera pública: o recrudescimento dos ânimos, das animosidades, e a crescente intolerância das condiçôes impostas ao processo de transição sugerem a minimização da Câmara como espaço de negociação e a adoção de novas táticas de pressionamento do Estado que inauguram uma nova etapa na mobilização, através da realização de protestos e passeatas - acompanhadas de reunióes extraordinárias - em frente ao prédio da Prefeitura Municipal. Esses eventos são interessantes na medida em que permitem pensar, de um lado, o processo de preparaçáo das disposiçóes emocionais dos comerciantes, mediados pela agência do líder, a fim de "enfrentar" o Estado e seus atores políticos na busca pela reciprocidade e pelo reconhecimento. De outro lado, sua riqueza estética e polifônica está em permitir reconstituir, a partir da expressão discursiva das emoçôes e narrativas, os valores e disposições que estáo em jogo do ponto de vista da atuação dos agentes estatais, do líder comunitário e ainda, nesse sentido, da comunidade de pertencimento, como perspectivas distintas de engajamento, duplamente mediadas pelo acionamento e pela expressão (poderíamos dizer) obrigatória das emoções (Mauss, 1979): os agentes estatais preocupados em contê-las, a comunidade em fazê-las aflorar (mas não de qualquer maneira) (Bakhtin, 1993) e o líder comunitário, em fazê-las dialogar para a pro- 
dução da eficácia simbólica de seu próprio discurso enquanto mediador político.

De modo que o encerramento do ciclo de reuniōes na Câmara coincidiu com a realização de dois protestos, durante os meses de agosto e setembro, acompanhados de reunióes extraordinárias com o secretário de Gestão e Planejamento, Clóvis Magalhães. Apesar das novas possibilidades de postergação das notificações de inadimplência decorrentes desses encaminhamentos, das incursóes pela mídia e pelas capas de jornais rendidas pelos eventos, o clima de expectativa e insegurança já tinha sido novamente tragado pelo cotidiano no Camelódromo - pontuado pelas exigências fiscalizadoras e disciplinadoras da empresa, em parceria com a fiscalização da SMIC, de um lado, e o baixo fluxo de vendas, de outro, que levava a um incremento exponencial e cumulativo das dívidas e, com elas, das preocupaçóes e confabulações. Uma reunião na SMIC, que veio a ocorrer no dia 22 de setembro de 2009, encerraria o ciclo de incursóes litigiosas pelos espaços públicos para discutir a questão. $\mathrm{O}$ evento contou com a presença de cerca de apenas 60 comerciantes populares - nem a confecção de um dossiê de mais de 200 páginas, uma espécie de processo ou "retrato" das irregularidades que caracterizariam os desvios no projeto gestado pelos comerciantes populares, estimulou o engajamento daqueles já excessivamente desgastados pelo processo. Em entrevista concedida logo na saída da sala de reunióes, o secretário Cecchim destaca que, apesar dos pontos apresentados e discutidos pelos camelôs, o problema seria de outra natureza:

O mais importante é que nós temos que fazer um trabalho conjunto, para os comerciantes prepararem-se para serem vendedores, para não ficarem passivamente esperando o comprador. [...] o problema não é só o valor do aluguel. Não é $50 \%$, $30 \%$ ou $20 \%$ que vai fazer a dife- rença, porque eles não pagaram nenhuma, e por isso que eu chamo muitas vezes de uma inadimplência política! Afinal de contas a maioria deles trabalhava das $18 \mathrm{~h} 30 \mathrm{~min}$ às $20 \mathrm{~h} 30 \mathrm{~min}$ só, na Rua da Praia. Então agora eles têm que trabalhar o dia todo, então fica difícil de se adaptar. [...] Anistia não existe! Essa palavra não... existe renegociaçâo! [Eles chegaram a pedir pra retornar pra rua?] É, isso não é um pedido sério, porque existe uma lei, e não é só a lei que não quer eles na rua. A populaçáo consagrou a rua para ser $l i$ vre! Porque a população rejeita a possibilidade de eles voltarem pra rua, e por isso nós tivemos o cuidado de fazer a lei na Câmara que não permite mais o comércio de camelôs no centro de Porto Alegre. Então essa ameaça de rua não existe!

Uma das principais consequências dessa reunião, portanto, está na instituição de um prazo - dia 15 de dezembro de 2009 - para o início do processo de renegociação das dívidas dos comerciantes populares, que deveriam, supostamente, propulsionar suas vendas a partir do início do ciclo das festas de fim de ano. De fato, os dois últimos meses do ano foram marcados pelo arrefecimento no processo de mobilização e articulação política da transição, ao mesmo tempo pontuado por um leve incremento na circulação e comercialização de mercadorias. Contudo, isso não se traduziu em tentativas de renegociação junto ao escritório da empresa que detém a concessão, situado no terceiro piso do prédio. De modo que, se as vendas de fim de ano conferiram novas esperanças e predisposiçóes subjetivas ao trajeto da transição, os meses de janeiro e fevereiro, pontuados pelo recesso comercial - que habitualmente desloca os consumidores e habitantes para fora da região central e mesmo da cidade - implicou uma nova inflexão na maneira como esses trabalhadores construíam as narrativas em torno da instituição e consolidação da experiência de legalização comercial e subjetiva. 
Durante os meses de janeiro e fevereiro, Juliano, acompanhado de seu habitual séquito de lideranças e alianças, esteve envolvido com o processo de discussão e implementação da "Lei do Fundo", que institui o repasse da receita arrecadada com o estacionamento do Camelódromo para um fundo administrado por um Comitê Fiscal que seria, por sua vez, gerenciado por representantes dos comerciantes populares. Após uma série de reunióes ocorridas no gabinete da vereadora Fernanda Melchionna em que, desde a filiação ou repartidarização de Juliano $^{15}$, se realizavam as confabulaçôes e concepção das estratégias políticas do movimento -, bem como de discussóes acaloradas nos bastidores da Câmara de Vereadores, entre os advogados da empresa, os vereadores envolvidos na discussão e a representação dos camelôs, o projeto seria finalmente aprovado, em plenário, no dia 15 de março de 2010.

Ao mesmo tempo, o mês de fevereiro foi pontuado pelo retorno das notificaçóes aos comerciantes inadimplentes, aqueles que não cumpriram o prazo de renegociação das dívidas, ainda em dezembro de 2009. A intensificação dos conflitos e as tentativas individuais de acordo com a empresa fizeram emergir novas reunióes e assembleias da ASFERAP, no terceiro piso do camelódromo - com vistas a fazer lembrar e revigorar a mobilização coletiva em torno do processo de transição. O episódio transcrito abaixo, extraído de uma dessas tentativas, ocorrida no dia 17 de fevereiro de 2010, dá o tom da ambiência em vigor àquela época, ao mesmo tempo em que coloca novamente a questão do Camelódromo nas páginas de jornal e noticiários televisivos.

- [Juliano] Naquela época [antes do dia 15 de dezembro] a gente já tinha entrado com uma ação jurídica, onde muitos e muitos daqui não quiseram entrar com a ação! Se naquele momento a gente dizia que era importante ter uma ação jurídica, independente das negociaçôes que viriam pela frente, muitos e muitos e muitos não acreditaram! Acharam que em função de uma vendinha que tinha começado em dezembro... $A$ gente é camelô!!! A gente sabe que em dezembro em toda a cidade, se botar um coco numa esquina, vende! [...] Nós estamos enfrentando aqui um capitalismo puro, selvagem, onde a dona Eloá não tem dinheiro, tchau, dona Eloá, não interessa se ela tem filho, não interessa! Vai embora e dá lugar pra outro! E aí ela vai lá e passa pro agenciador que ta comprando banca aqui dentro!!! E tem pessoas que tão vendendo e tão ajudando o cara a comprar e a vender! E tão esquecendo que existe um movimento! Se nós perder o espaço aqui dentro nós estamo morto!!! 20, 15, 10 anos de luta que é a nossa herança, a gente sempre dizia, e isso nós não podemos perder! E é só a mobilização que vai segurar o processo!!

- Eu confioooooo [palmas e gritos]!!!! Eu confio no movimento!!!

- Eu não vou vender a minha bancaaa!!! Não vou!!!

- Houve um momento de desmobilização aqui, seu Luís! Porque as pessoas ficaram deslumbradas que venderam 300,500 reais num dia, e esqueceram que a dona Eva ta vendendo 10, que a dona Maria não ta vendendo nada! Todo mundo sabia, mas parece que deu uma amnésia. O dinheiro faz isso com as pessoas! As pessoas se esquecem o que passou e o que pode vim! Nós não podemos esquecer o que nós passamos na rua! As pessoas esqueceram desse movimento! Não pode esquecer!!! E daqui pra frente, dona Maria, a coisa pode apertar mais, mas só vai apertar se a gente pensar com a cabeça no individual! Se a gente pensar que um precisa ajudar o outro, eles não entram no nosso núcleo, eles não entram [aplausos e gritos]!!!

De modo que, na quinta-feira, dia 11 de março, a SMIC, apoiada pela Brigada Militar, dá início ao processo de despejo dos primeiros 
comerciantes populares inadimplentes. Invade a banca de dona Isolda, diante dos gritos e xingamentos de protesto de camelôs que se interpuseram às açóes da polícia, encetando, assim, o confronto direto. Um dos comerciantes, seu Zé, teve o braço ferido pela ação dos brigadianos que, então, lacraram a banca de dona Isolda e se dirigiram até o box de Juliano. De maneira a se precaver do que esperavam que pudesse acontecer, dona Diva e dona Marilda, colegas e vizinhas de banca, esvaziaram e distribuíram os pertences que ainda estavam no box de Juliano, de modo que, ao chegarem ao local, os fiscais encontraram poucas mercadorias e materiais de exposição. Realizaram o mesmo procedimento e, diante da imprensa que já havia chegado e acompanhava os gritos e tentativas eufóricas de impedirem a "tomada" à força dos espaços, retiraram-se do Camelódromo. Algumas pessoas ainda tentavam violar, mesmo que simbolicamente, o lacre instituído pelo poder público, arremessando artefatos, cadeiras e outros pertences contra os cadeados que haviam sido instalados nas trancas. Alguns dias transcorridos, e a SMIC realiza a interdição sigilosa, durante a noite, de mais sete bancas do bloco B, além do fechamento das duas que já haviam sido lacradas na semana anterior. $\mathrm{Na}$ terça-feira, boa parte dos camelôs que tiveram suas atividades suspensas pelo setor de fiscalização não comparece ao camelódromo, mantendo, assim, o lacre intacto, em função das possíveis penalizaçóes jurídico-administrativas.

Uma última reuniāo seria ainda convocada pela Promotoria Pública para a discussão das possibilidades de suspensão das interdições e despejos. Contudo, a eleição do novo Comitê Gestor, em abril - que contou com a impugnação da chapa apoiada por Juliano e a eleição de comerciantes associados ao bloco A e ao governo - , viria a arrefecer qualquer nova tentativa de resistência do grupo presidido por Juliano. Por fim, a confirmação do encerramento deste primeiro ciclo de transição ficaria claro, ainda, com o anúncio da candidatura de Juliano Fripp a deputado estadual - que revela uma alteração significativa nas estratégias de condução dos trabalhos relativos à presidência da ASFERAP e, ainda, em termos de circulação e frequentação de espaços institucionais por onde constituir a sua reputação como liderança. Sem abandonar totalmente o espaço-tempo do Camelódromo - afinal, volta e meia ainda se fazem observar e circular pelos corredores papéis e manifestos assinados por Juliano na tentativa de chamar a comunidade de sentido que realizou, com ele, o primeiro ciclo da transição Juliano procura revigorar a rede de alianças e reciprocidades constituída no Camelódromo, na ASFERAP, no Orçamento Participativo, a fim de converter esse acúmulo de capitais em um potencial apoio político à sua candidatura. Ao mesmo tempo, não deixa de estar engajado com os camelôs que permaneceram em suas bancas, muitos deles tão ou mais endividados quanto ele à época do despejo, e atualmente envolvidos com açóes jurídicas de expropriaçáo ou renegociação de valores, a partir de processos individuais impetrados pela empresa.

\section{Consideraçóes finais}

Ao primar pelo processo de reconstituição do primeiro ciclo de transição subjacente à instituição e consolidação das experiências do Camelódromo em Porto Alegre, do ponto de vista da politização dos símbolos, narrativas e sentimentos que pontuaram a percepção de um grupo particular de camelôs à testa do processo, este trabalho procurou dar destaque ao empoderamento da discussão sobre o deslocamento e a produçáo desse novo sujeito perquirido e forjado pela intervenção do Estado na esfera social e econômica. Ao invés de indagarmo-nos a respeito de uma discus- 
são dicotômica que opóe a lógica do cidadão moderno, auto-evidente e auto-referenciado em termos de práticas de comercialização, à lógica do sujeito intrincado e abalroado pelas experiências coletivas que fazem a reinvenção da rua no interior do camelódromo, é possível recolocar a questão, invertendo a ordem dessas proposiçóes teóricas, de modo a perguntarmo-nos a respeito, propriamente, de uma espacialidade e temporalidade específicas da transição, materializada pelo protótipo de comerciante popular condensado pela ASFERAP. Trata-se de pensar o deslocamento enquanto um movimento incessante de vai e vem, ora pendendo para uma direção, ora para a outra: é a própria fronteira entre o mundo do projeto individualista e o campo de possibilidades holista do camelô da rua que precisa ser repensada a favor de uma fronteira cuja espessura, mais ou menos variável, permite adequar e articular esses universos de significação na constituição de uma experiência de transição sui generis.

Não é outra a razão que explica a dinâmica e efemeridade com que posiçóes, alianças e rompimentos nesse campo são alterados: ora flerta-se com a mídia, ora com o empreendedor, ora com os vereadores, ora com a Prefeitura ou a Secretaria de Indústria e Comércio. Trata-se de um constante formular e reformular essas experiências, de construir, de legitimar, de autorizar, de destituir ou de desresponsabilizar os símbolos, objetos e narrativas que compóem o repertório de significação e dramatização do deslocamento. Assim, a busca pela politizaçáo dos símbolos e narrativas produzidos pelo deslocamento - que conduz à formação de alianças, reciprocidades, mas também de clivagens e oposições - obedece à mesma fluidez e dinâmica com que são alternados os estados emocionais e perceptivos, ora de adesão, ora de rompimento, de formação desse novo individuo comerciante (esta última também uma categoria incompleta, cuja variedade de classificaçôes e rotulaçôes certamente coloca um campo privilegiado para o entendimento desses problemas). Se o projeto do Camelódromo conduz, a longo prazo a partir da legalização econômica e jurídica, inevitavelmente, à incorporação de uma simbologia cosmológica (discursiva, econômica, social, corporal e emocional), através de um reajustamento global, existencial e multidimensional da sensibilidade pela qual o indivíduo percebe a si mesmo, ao mundo e à realidade que o circunscreve, importa captar as singularidades desse processo de transição enquanto um espaço de construção perceptiva da realidade, dessa construção de si, que conduz a diferentes modalidades e agenciamentos de subjetividades (Foucault, 1984; 1985) e, destarte, a acepções e percepções heteróclitas do que é ser moderno, estar na história, no Camelódromo e, portanto, na condição de "comerciante popular".

\section{Politics, economy and symbolic media- tion: ethnographic notes on the constitution of social chieftainship build on the experien- ce of Porto Alegre's Camelódromo.}

abstract This article emphasizes on the disputes and organization processes of a popular shopping center - called "Camelódromo" - located in downtown Porto Alegre/RS. Based a multi-sited participant observation, this paper argues, on the one hand, governmentality strategies associated to the state's persuasive force by relating the necessity of sanitation and urbanization of the public space to the spatial and identitarian displacement of informal workers from the streets to the juridical-formal visibility. On the other hand, questions the models of state management underlying the public-private partnership by contextualizing them through the view of the camelôs vendors affected by the transition process. The ethnographic accompaniment of their community leader - Juliano Fripp - and the connection of the different spaces of the public 
sphere (City Council, Prosecutor, City Hall and the Participative Budget), both linked to the group's expectations; allows to see how the more broader tensions about political and economical processes are configured by the organization processes of the "Camelódromo".

keywords Camelódromo. Transition. Informal trade. Political mediation. State.

\section{Notas}

1. Parte deste trabalho foi apresentada durante a $27^{\mathrm{a}}$. Reunião Brasileira de Antropologia, realizada entre os dias 01 e 04 de agosto de 2010, Belém, Pará, Brasil.

2. De acordo com o site da prefeitura de Porto Alegre, uma PPP "é uma parceria onde o setor privado projeta, financia, executa e opera uma determinada obra/serviço, objetivando o melhor atendimento de uma determinada demanda social. Como contraprestação, o setor público paga ou contribui financeiramente, no decorrer do contrato, com os serviços já prestados a população, dentro do melhor padrão de qualidade aferido pelo Poder concedente". No caso do Camelódromo, trata-se de uma concessão de área pública à iniciativa privada, que poderá explorar integralmente o espaço durante 25 anos, sem contrapartida financeira direta do poder público sobre esses encargos de locação.

3. As principais modificaçôes previstas pela reurbanização do centro estão colocadas no programa "Viva o Centro", que "procura estimular, além do seu caráter predominantemente de comércio e serviços da área central, outras vocaçóes importantes e compatíveis com seu potencial econômico, cultural e ambiental, melhorando as condiçôes gerais do bairro. Volta-se, desta forma, para questôes como a paisagem, a recuperação de prédios e áreas públicas, o transporte coletivo e individual, a segurança, a moradia e o comércio informal. $\mathrm{O}$ trabalho é desenvolvido através de um conjunto de açôes". Dados extraídos do site http:// www2.portoalegre.rs.gov.br/vivaocentro/, acessado em 18.07.2010.

4. O camelódromo conecta a Avenida Voluntários da Pátria à Mauá, através de uma passarela de dois corredores que entrecruzam a avenida Julho de Castilhos -, ao mesmo tempo em que estabelecem uma clivagem entre os blocos A e B do empreendimento. Simultaneamente uma divisão física e metafórica, cumpre observar, do ponto de vista antropológico, as apropriações simbólicas dessa diferenciação, isto é, os modos pelos quais as diferenças na alocação e distribuiçáo de comerciantes populares oriundos de diferentes segmentos da rua e perspectivas de engajamento são ressignificadas, com base na arquitetura e dos espaços estratégicos do prédio, em termos de uma oposição entre o bloco A e o bloco B do prédio.

5. Cabe, aqui, uma nota acerca do recorte metodológico em torno da figura do líder comunitário: sua trajetória converte-se em uma série de dispositivos de acesso privilegiados aos contextos mais amplos de disputas a partir dos quais suas performances públicas têm fundamento; isto é, como um ponto de vista particular, ainda assim coletivo - como uma posição social dada no campo de forças e de possibilidades culturais -, que é atravessado pelos processos globais e macro-sociológicos em desenvolvimento, num dado recorte temporal e espacial específico. O que interessa captar não é o conjunto de experiências de um grupo de indivíduos contado através da história de um caso exemplar, mas pensar como grandes processos globais de significação econômica e política operam no reordenamento subjetivo de categorias de apreensão da realidade.

6. De fato, a seleção deste evento como ponto de ruptura para o início da transição é aleatória e cumpre tão somente o papel de definir, do ponto de vista temporal, o marco desse deslocamento. Como as próprias narrativas de Juliano deixam entrever, o tempo narrado da transição é tão variado quanto o são as experiências biográficas distintas de cada um dos sujeitos afetados, e não raro fazem referência há várias décadas anteriores, simultâneas ao início da atividade informal, nas ruas de Porto Alegre.

7. Excerto de discurso proferido durante Reunião na Comissão de Direitos Humanos/Câmara, 28/08/2008.

8. Excerto de discurso proferido durante Reunião na Comissão de Direitos Humanos/Câmara, 28/08/2008.

9. Um dos espaços privilegiados de enunciação e problematização dessas questões, ao longo dos anos prévios à inauguração da obra, e que representou, para a ASFERAP, um dos elementos fundamentais de instrumentalização e empoderamento para a realização desse debate (tanto em termos das possibilidades de discussão do tema, quanto em relação às habilidades discursivas acionadas para a expressão na arena pública), foi o Fórum Regional de Delegados e Conselheiros (FROP) da Região Centro do Orçamento Participativo de Porto Alegre. Ao longo 
dos dois anos em que acompanhei sistematicamente as reuniōes semanais realizadas na Sala 10 do Mercado Público, observei a dinâmica da constituição e do rompimento estratégico das alianças e reciprocidades que se desenhavam em torno da discussão sobre a finalização da obra, de um lado, e a tensão subjetiva da transposiçáo, de outro. Juliano, de forma particular, ocupou as instâncias diretivas do FROP Centro como delegado e conselheiro durante vários mandatos consecutivos, além de ter participado, no último mandato, como conselheiro da Temática de Desenvolvimento Econômico.

10. Durante todo o ano de 2008, a constante exposiçáo à mídia em função dos conflitos com outros setores e agentes sociais envolvidos na disputa pelo Camelódromo, bem como as diversas manifestaçóes públicas em favor da rediscussão do projeto e da transposição dos camelôs, fizeram-no candidatar-se a vereador de Porto Alegre, pelo PCdoB. Apesar de seu prestígio político e das várias incursóes durante a campanha pelas comunidades da Regiáo Centro do OP, em que se consolidou como liderança, Juliano fez cerca de 900 votos, o que o colocou numa distante posição de suplência, muito aquém de suas aspiraçôes iniciais.

11. Excerto de discurso proferido na Reunião da Comissão de Direitos Humanos/Câmara, 28/08/2008.

12. Essas narrativas, de fato, não fazem outra coisa que dramatizar, por homologia, o "destino", imaginado por esses comerciantes populares, de seu próprio processo de transição diante de uma conversão ao projeto de self proposto pelo Camelódromo, impossível de ser concebido integralmente: resistir-se-ia com todas as "fissuras" da transposição, enquanto fosse possível (por homologia a uma serie de postergaçóes da inauguração do prédio, em decorrência de "fissuras" e "rachaduras" no prédio que abalaram a sua segurança), até que o despejo se tornasse o fim inevitável (por homologia à morte dos comerciantes através da sucumbência da infraestrutura diante de todas as irregularidades apresentadas).

13. Declara triunfalmente o jornal Zero Hora, 04/02/2009: “O fim da novela 'Camelódromo' - Enfim, a prefeitura conseguiu a liberação para o funcionamento do Centro Popular de Compras. A vistoria da Smov, nessa tarde, não constatou irregularidades. Com isso, o tão esperado Habite-se já está nas mãos do - agora aliviado - secretário da Smic, Idenir Cecchim. É o desfecho de uma novela que se arrastava por semanas. É o início de um novo centro de Porto Alegre com o fim dos camelôs na Praça XV e na José Montaury”.
14. A escada de acesso ao segundo pavimento do Camelódromo (onde funcionam as lojas) funciona, de fato, como o operador, por excelência, da transiçáo, desse movimento que conduz do corredor da rua para o corredor do prédio, da informalidade em direção à legalidade. É ela que faz a fronteira, ao mesmo tempo em que media e articula, isto é, cria uma comunicação metafórica que separa a imagem do passado e do devir. Não é por outra razão que alguns comerciantes populares referem-se com desdém aos "cavalos" ou camelôs que ocupam a escada de acesso, na tentativa de chamar clientes para o Camelódromo, para as lojas da Voluntários da Pátria, ou mesmo na tentativa de comercializar produtos falsificados, expostos, por sua vez, em um "catálogo" que carregam à mão.

15. Juliano foi, desde os anos 90, militante e ativista do PCdoB, cujas ideias e perspectivas estão subjacentes, de alguma maneira, na própria economia discursiva e corporal que caracteriza as suas performances. Ao longo do processo de mobilização, em 2009, a presença cada vez mais engajada e incisiva da vereadora Fernanda, demonstrando interesse em sua filiação, convenceram-no de que o melhor a fazer seria a conversão ao PSOL, partido pelo qual Juliano lançaria sua candidatura a deputado estadual, em 2010.

\section{Referências bibliográficas}

BAKHTIN, Mikhail. "Introdução - a apresentação do problema”. In: A cultura popular na Idade Média e no Renascimento. São Paulo: Hucitec/Editora UnB, 1993. BOURDIEU, Pierre. "Espírito do Estado. Gênese e estrutura do campo burocrático". In: Razóes Práticas. Campinas: Papirus, 1996.

"O ser social, o tempo e o sentido da existência". In: Meditações Pascalianas. Rio de Janeiro: Bertrand Brasil, 2001.

"Esboço de uma teoria da prática". In: ORTIZ, Renato (org.). Pierre Bourdieu. São Paulo: Ática, 1983, p. 46-81.

CLASTRES, Pierre. "O dever de palavra"; "A Sociedade contra o Estado". In: A Sociedade contra o Estado. 5a ed. Rio de Janeiro: Francisco Alves, 1979, p. 149-211.

CRAPANZANO, Vincent. Horizontes imaginativos e o aquém e o além. Revista de Antropologia, São Paulo, v. 48, n.1, p. 363-384, 2005.

DE CERTEAU, Michel. A invenção do cotidiano. Petrópolis: Vozes, 1994. 
50| MoISÉs Kopper

FOUCAULT, Michel. "A cultura de si". In: História da Sexualidade 3. O cuidado de si. Rio de Janeiro: Ediçōes Graal, 1985, pp. 43-75.

"A Governamentalidade". In: Microfisica do Poder. Rio de Janeiro: Graal, 1979.

"Introdução. A problematização moral dos prazeres". In: História da Sexualidade 2. O uso dos prazeres. Rio de Janeiro: Graal, 1984, pp. 7-32.

GHASARIAN, Christian. "Art oratoire et citoyenneté participative à Rapa”. In: NEVEU, Catherine (org.). Cultures et Pratiques Participatives. Paris: L'Harmattan, 2007.

LEITE, Rogerio Proença. Contra-Usos e Espaço Público: notas sobre a construção social dos lugares na Manguetown. Revista Brasileira de Ciências Sociais, São Paulo, Vol. 17, n. 49, junho/2002, pp. 115-134.
Espaço público e politica dos lugares: usos do patrimônio cultural na reinvenção contemporânea do Recife Antigo. Tese de Doutorado. Instituto de Filosofia e Ciências Humanas, Unicamp, Campinas, 2001.

MAUSS, Marcel. "A expressão obrigatória dos sentimentos”. In: CARDOSO DE OLIVEIRA, Roberto (org.). Marcel Mauss. São Paulo: Ática, 1979.

SAHLINS, Marshall. O "Pessimismo Sentimental" e a Experiência Etnográfica: por que a cultura não é um "objeto" em via de extinção. Mana, Rio de Janeiro, v. 3, n. ${ }^{\circ} 1$, p. 41-73, 1997.

SOUZA LIMA, Antonio Carlos. Introdução. In: (org.). Gestar e Gerir. Rio de Janeiro: Relume Dumará, 2002.

VELHO, Gilberto. Individualismo e cultura. Notas para uma antropologia da sociedade contemporânea. Rio de Janeiro: Zahar, 1981.

\section{autor Moisés Kopper \\ Mestrando em Antropologia Social / UFRGS}

Recebido em 07/02/2011

Aceito para publicação em 26/09/2011 